NBER WORKING PAPER SERIES

\title{
SOURCES OF CORPORATE FINANCING AND ECONOMIC CRISIS IN KOREA: A MICRO-EVIDENCE
}

Youngjae Lim

Working Paper 9575

http://www.nber.org/papers/w9575

\author{
NATIONAL BUREAU OF ECONOMIC RESEARCH \\ 1050 Massachusetts Avenue \\ Cambridge, MA 02138 \\ March 2003
}

This paper was prepared for the volume on Governance, Regulation and Privatization that is being edited by Takatoshi Ito and Anne O. Krueger for the NBER and will be published by the University of Chicago Press. We thank Anne O. Krueger as well as participants of the conference on Governance, Regulation and Privatization in Hong Kong for helpful comments. The views expressed herein are those of the authors and not necessarily those of the National Bureau of Economic Research.

(C2003 by Youngjae Lim. All rights reserved. Short sections of text not to exceed two paragraphs, may be quoted without explicit permission provided that full credit including Cnotice, is given to the source. 
Sources of Corporate Financing and Economic Crisis in Korea: A Micro-evidence

Youngjae Lim

NBER Working Paper No. 9575

March 2003

JEL No. G3, G2, N2, O1

\begin{abstract}
$\underline{\text { ABSTRACT }}$
Using the firm-level data set, the paper attempts to examine the dynamic patterns in the allocation of credit across firms in recent Korea. In particular, the paper examines the dynamic patterns in the allocation of credit across large and small firms before and after the crisis. The data suggest that large firms, to some extent, are leaving banks and going to the capital market for their financing after the crisis. The data also suggest that profitable small firms are gaining easier access to the credit from financial institutions after the crisis. Is this shift (in the allocation of bank credit from large firms to small firms) due to lenders' choice or due to borrowers' changed incentives? The paper suggests that the improved lending practices of banks, at least partially, contributed to this shift of bank credit from large firms to small firms.
\end{abstract}

Youngjae Lim

Korea Development Institute

P.O. Box 113, Cheongryangri

Seoul 130-012, KOREA

yjlim@kdi.re.kr 


\title{
Sources of Corporate Financing and Economic Crisis in Korea:
}

\section{A Micro-evidence}

\author{
Youngjae Lim
}

\section{Korea Development Institute}

\section{Introduction}

Using the firm-level data set $^{1}$, this paper attempts to examine the dynamic patterns in the allocation of credit across firms in recent Korea. Supposedly, in Korea, the economic crisis in 1997 had a significant impact on the pattern in the allocation of credit across firms. In particular, this paper aims to examine the dynamic patterns in the allocation of credit across large and small firms after the crisis.

Corporate financing issues are intimately related to the cause of the Korean crisis. For instance, the chaebols' indebtedness to banks is viewed as having contributed much to the crisis. Among others, Krueger and Yoo (2001) demonstrate that the chaebols' indebtedness is indeed the chief culprit of the crisis. Since the outbreak of the financial crisis in 1997, the government has undertaken various reform measures to restructure the financial and corporate sectors. The new regulatory system is now underway to induce the financial institutions to change their imprudent lending practices, and the capital market began to force the chaebols to correct their incentive structure. Supposedly, these post-crisis developments in Korea have caused the chaebols and 
financial institutions to change their previously imprudent (borrowing and lending) practices.

The paper suggests that large firms, to some extent, are leaving banks and going to the capital market for their financing after the crisis. The paper also suggests that profitable small firms are gaining easier access to credit by financial institutions after the crisis. There has been a shift in the allocation of bank credit from large firms to small firms. Is this shift due to lenders' choice or due to borrowers' changed incentives? The paper suggests that the improved lending practices of banks, at least partially, contributed to this shift of bank credit from large firms to small firms.

This paper is organized as follows. In Section 2, we provide the aggregate data on the corporate financing sources in recent Korea. Section 3 explains the firm-level data set. In Section 4, we examine the dynamic patterns in the allocation of credit across firms. Section 5 concludes the paper with agenda for future research.

\section{Aggregate Patterns in the Corporate Financing Sources}

In $<$ table $1>$ we show the aggregate data for the sources of corporate financing before and after the economic crisis. We calculated the numbers in $<$ table $1>$ from the information given in various issues of the Flows of Funds by the Bank of Korea.

//Table 1 here//

The main reason we present this table is that it decomposes indirect finance further into the detailed sources (commercial banks, insurance companies (including pension funds), short-term finance companies (e.g., merchant banks), and other non-bank financial intermediaries). Another point in the table is that it has been constructed by aggregating all the financial transactions for all

\footnotetext{
${ }^{1}$ The data set covers most of the Korean firms except for extra-small ones.
} 
the firms in the Korean economy. Hence, we could use this table for the check of the consistency in the firm-level data, for example, whether there is any systematic bias in the firm-level data due to the exclusion of extra-small firms.

After the crisis, in 1998-9, the share of external finance in the total finance sharply declines to $50 \%$ from about $70 \%$ throughout the 90 's until $1997^{2}$.

In 1998, as expected, the crisis changes completely the table for corporate financing sources. However, in 2000 when the crisis phases out, the table for corporate financing sources takes a somewhat different composition compared to before the crisis.

First of all, the share of indirect finance does not recover the level before the crisis. A look into the components of indirect finance is necessary. The non-bank financial intermediaries, except for insurance companies, lose their share significantly compared with before the crisis. On the other hand, the share of commercial banks increases to almost double the average level before the crisis. Second, in 2000, the composition of direct finance changes compared to before the crisis. Equity takes away the share of the borrowing from financial markets (commercial paper, bonds, etc). Lastly, foreign borrowing increases its share significantly.

\section{The Firm-level Data}

This study uses detailed financial information on the firms that have external audit reports. According to the Act on External Audit of Joint-Stock Corporations, a firm with assets of 7 billion

\footnotetext{
${ }^{2}$ Although not shown in the table, the share of external finance in the total finance declined steadily throughout the 1970's and 1980's until 1988. For this period, except for the period of oil shocks, overseas export markets, together with emerging domestic markets, helped Korean firms to realize large profits. The ratio of internal finance to total finance was less than 20 percent in 1975, but it continued to grow to a level of more than 40 percent in 1988 .
} 
won or more must issue audited financial statements. The data thus include all the firms with assets of 7 billion won or more. The total number of firms in the data is about 11,000 .

The Financial Supervisory Commission is responsible for establishing accounting and auditing standards and the Securities and Futures Commission is then responsible for the review of the audited financial statements issued by firms. Finally, the National Information and Credit Evaluation, Inc. (NICE) coded this public information into their database after checking the consistency of the reported financial statements.

From the NICE data, we can estimate only the borrowing from all the financial intermediaries, not the borrowings from the detailed components of indirect finance. However, $<$ table $1>$ in Section 2 shows that, after the crisis, most of the new lending by financial intermediaries is, in fact, from commercial banks, not from non-bank financial institutions.

\subsection{Summary Statistics}

$<$ Table 2-1> presents sample means for the key variables in the empirical analysis It divides the sample period into the three sub-period around the crisis: 1992-1996 (before the crisis), 1997-1998 (during the crisis), and 1999-2000 (after the crisis). Profitability is measured by the EBIT (Earnings Before Interest and Tax Payment) divided by total assets. divided by total asset. After the crisis, the share of loans in asset increases compared with for the pre-crisis period; on the other hand, the weight of bond financing decreases.

//Table 2-1 here//

The financing pattern varies according to the size of firms. For example, the empirical distribution of the loans' share in total asset has a different shape according to the size of firms. For 
this reason, we divide all individual firms into ten groups based on the distribution of asset size, and select three representative size cohorts for presenting the empirical results. The results are robust to minor changes in the thresholds. We employ the following three size cohorts: (1) the largest firms (top $1 \%$ in asset size) $)^{3},(2)$ the medium-sized firms (middle $10 \%$ in asset size), and (3) the smallest firms (bottom $10 \%$ in asset size).

For the three size cohorts, <table $2-2>$ provides sample means for the key variables in the empirical analysis It also divides the sample period into the three sub-period around the crisis.

//Table 2-2 here//

The statistics in $<$ table $2-2>$ present a different picture compared to the one in $<$ table $2-1>$. The aggregate numbers in <table 2-1> do not fully capture the changes in the financing pattern experienced by heterogeneous firms during this period. Profitability evolves differently according to size groups. Profitability worsens for large and small firms whereas it rebounds for mediumsized firms. While the share of loans in asset decreases for large firms, the opposite is the case for the other groups. After the crisis, large firms finance more in the bond market, but the other groups have more limited access to the bond market compared to the pre-crisis period.

\subsection{Firm Size Distribution}

$<$ Figure 1-1 $>$ and $<$ figure 1-2> show the yearly firm-size distributions for all the firms in the sample before and after the crisis. Before the crisis, the distribution shifts to the right-hand side implying an increase in firm size on average. The shape of the distribution gets skewed to the right gradually over time until 1997 . We find relatively less small-sized firms over time in the

\footnotetext{
${ }^{3}$ For the case of large firms, we present the results using this particular cohort, but defining the largest firms as differently like the top $5 \%$, or top $10 \%$, does not change the qualitative results of the paper.
} 
yearly distributions.

//Figure 1-1 here//

//Figure 1-2 here//

After the crisis, it is hard to find a clear pattern in the shift of the distribution itself. However, the left-hand tail of the distribution - the smallest firms in the sample - becomes thicker after the crisis. The relative frequency of the smallest firms in the sample increases after the crisis. This thicker right tail could come either from an increased number of new entrants or from the inclusion of extra-small firms (previously excluded from the sample) into the sample. Note that we observe the opposite before the crisis - the left-hand tail of the distribution getting thinner.

\subsection{Firm Profitability Distribution}

$<$ Figure $2-1>$ and $<$ figure $2-2>$ present the yearly profitability distributions for all the firms in the sample before and after the crisis. The yearly distributions remain the same before the crisis. Then the crisis affects significantly the profitability distribution in 1997, indicating a decrease in firm profitability on average. After the crisis, the profitability distribution shifts much to the right or left depending on the macroeconomic situations. In fact, after the crisis, the magnitude of business cycle became larger than compared to the pre-crisis period. ${ }^{4}$

//Figure 2-1 here//

//Figure 2-2 here//

$<$ Figure 2-3> shows that the small- and medium-sized firms have more dispersed distributions

\footnotetext{
4 The annual growth rates of GDP after the crisis are 5.0\% (1997), -6.7\% (1998), 10.9\% (1999), and 8.8\% (2000), whereas, before the crisis, the difference between the peak and trough years dos not exceed $4 \%$.
} 
in 1992-2000. Since this pattern remains the same in the sample period, we do not present the yearly distributions here. Large firms are more homogeneous in terms of profitability compared to the other size cohorts.

//Figure 2-3 here//

$<$ Figure 2-4-1 $>$ and $<$ figure 2-4-2 $>$ show that the crisis had an impact on the shape of the profitability for small firms. After the crisis (1997-2000), the distribution gets more dispersed over time. After the crisis small firms become a more heterogeneous group compared to the precrisis period.

//Figure 2-4-1 here//

//Figure 2-4-2 here//

\section{Financing Pattern and the Crisis: Micro Evidence}

In Section 3.1, the summary statistics of key financing variables hint that the heterogeneity of firms is important in understanding the evolution of financing pattern after the crisis. The sample means of key financing variables also hint the following pattern around the crisis: the largest firms are leaving financial intermediaries and switching directly to the financial markets for their financing, whereas the small- and medium-sized firms are increasing their dependency on financial intermediaries for financing. In this section, we test these hypotheses rigorously. To get genuine cross-sectional results, we must control for the effect of the business cycles.

The empirical distributions of key financing variables have different shapes according to the size of firms and evolve differently after the crisis. In this section, therefore, we also present the 
result of comparing the empirical distributions of key financing variables.

\subsection{Loans from Financial Institutions}

$<$ Table $3>$ shows the regressions of the loan-borrowing ratio (defined as the borrowing from financial intermediaries divided by total borrowing) on the dummy variables denoting the size cohort interacted with year dummies and on the macro variables (growth rate of GDP, interest rate). The macro variables control for the effect of business cycles. In $<$ table $3>$, therefore, the reported coefficient for the specific year indicates the loan-borrowing ratio's difference between the size cohort in that specific year and all the other firms in the whole sample period. $<$ Table $3>$ shows the regression results for the three size cohorts (top 1\%, middle 10\%, bottom 10\%).

//Table 3 here//

After the crisis (in 1998-2000), the largest firms decrease significantly the share of loans in total borrowing. The coefficients for 1998-2000 are larger than 0.3 (all significant), whereas the coefficients for 1992-1997 are smaller than 0.2 (also all significant). That is, after the crisis, the largest firms are leaving financial intermediaries for their financing.

For the small-sized firms this share jumps to a higher number from 1995 and stays more or less there even after the crisis. The coefficients for 1992-4 are smaller than -0.2 (all significant), whereas the coefficients for 1996-2000 are larger than zero (in 1995, -.0.03); these coefficients are all significant except in 2000. The small firms did not have much access to financial intermediaries in 1992-4, but they have better access to the loans from financial intermediaries afterwards.

For the medium-sized firms, the share of loans in total borrowing does not show any marked 
trend around the crisis. Note that the summary statistics in Section 3.1 suggested a different interpretation as for the behavior of medium-sized firms.

\section{< Empirical Distribution of Loans for Different Cohorts>}

$<$ Figure 3-1-1 $>$ and $<$ figure $3-1-2>$ show the distribution of the loan-borrowing ratio for the largest cohort (top 1\% firms in asset size) before and after the crisis. After the crisis (in 19982000), the loan-borrowing ratio distribution for the largest firms shifts leftwards clearly, as seen in $<$ figure 3-1-2>. This leftward shift starts partly in 1997 during the crisis.

//Figure 3-1-1 here//

//Figure 3-1-2 here//

For the small-sized firms (bottom 10\% firms in asset size) the distribution the loan-borrowing ratio shifts to the right markedly in 1996 (actually in 1995, although not shown in the paper) and maintains more or less this pattern even after the crisis ( $<$ figure $3-2-1>$ and $<$ figure $3-2-2>$ ).

//Figure 3-2-1 here//

//Figure 3-2-2 here//

In $<$ figure 3-2-1>, we note that, until 1994, a certain portion of the firms in our database does not have access to financial intermediaries for their corporate financing. One could see a certain dense around zero. However, after 1994, this pattern changes: the dense around zero continue to disappear until 1997, and, after the crisis, a dense around zero appears again, but to a much smaller scale than before 1995. <Figure 3-2-1> and <figure 3-2-2> make another interesting point. After 1994, we continue to see a peak at one and a certain mass around one, which indicates that these firms depend (or do not depend) completely on the loans from financial intermediaries for their borrowing. 
For the medium-sized firms, the share of loans in total borrowing does not show any marked changes before and after the crisis, except that, after the crisis, we could see a more cluster around one ( $<$ figure 3-3-1 $>$ and $<$ figure 3-3-2 $>$ ).

//Figure 3-3-1 here//

//Figure 3-3-2 here//

\subsection{Determinants of the Changes in the Allocation of Loans}

Why do we observe such shifts in allocation of loans by financial institutions as documented in Section 4.1? Are they reflecting the firms' spontaneous choice for financing sources as a result of corporate restructuring? Or, did the financial reform cause financial institutions to shift their lending patterns? To see whether this is the case, we attempt to test the effect of individual firm profitability on the shift in allocation of loans by financial institutions.

$<$ Table $4>$ shows the regressions of the change in loans on firm profitability (interacted with year dummy) for small firms. We also test the effect of the affiliation with chaebols on the access to loans. The chaebol dummy distinguishes the top 30 chaebols from the others.

//Table 4 here//

$<$ Table $4>$ suggests the interpretation that, for the small firms, profitability is an important factor in determining access to loans by financial institutions after the crisis. ${ }^{5}$ Financial institutions actively search for profitable small firms to provide loans after the crisis. In Section 3.4, we pointed out that that the crisis had an impact on the shape of the profitability for small firms. The profitability distribution becomes more dispersed after the crisis. It means that selecting efficient

\footnotetext{
${ }^{5}$ For medium-sized and large firms, the regression of the change in loans on firm profitability did not produce
} 
small firms became more difficult after the crisis.

Before the crisis, profitability was not a factor in the access of small firms to loans; on the contrary, inefficient small firms did have more access to loans by financial institutions. This reflects the fact that small firms were much protected through various regulations by the government before the crisis. Note that the affiliation with chaebols has a negative effect on the access to loans. In Korea, small firms affiliated with chaebols usually do not get the protection but rather face tight regulations to the effect of protecting other independent small firms. This kind of regulations is gradually shrinking after the crisis.

\subsection{Total Borrowing}

In Section 4.1, it is suggested that the largest firms are leaving financial intermediaries for their corporate financing after the crisis. Then, the question arises: do the large firms decrease investment and scale down their business? Otherwise, do they find other sources of financing after the crisis? To check this, we look at total borrowing before and after the crisis.

$<$ Table $5>$ shows the regressions of the borrowing-dependency ratio (defined as total borrowing divided by total assets) on the dummy variables denoting the size cohort interacted with year dummies and on the macro variables (growth rate of GDP, interest rate). In $<$ table $7>$, the reported coefficient for the specific year indicates the borrowing-dependency differences between the size cohort in that specific year and all the other firms in the whole sample period. <Table 5> shows the regression results for the three size cohorts (top 1\%, middle $10 \%$, bottom $10 \%$ ).

//Table 5 here//

meaningful results. 
The crisis affected the borrowing-dependency ratio of all the cohorts only during the crisis. When the crisis dies out, the borrowing-asset ratio returns to the previous trend. The share of borrowing in total assets went up much more for the small-sized firms during the crisis than the other size cohorts. Unlike the others, small firms didn't have other cushions (e.g., equity, retained earnings) to absorb the adverse effect of the crisis.

\subsection{Financing in the Bond Market}

The above result implies that the large firms moves to some other sources of financing after the crisis. This section will show that the large firms go to the bond market to compensate the decrease in loans by financial institutions. This was hinted in Section 2.1. We test it formally in the following.

$<$ Table $6>$ shows the regressions of the bond-borrowing ratio (defined as the borrowing from financial markets divided by total borrowing) on the dummy variables denoting the size cohort interacted with year dummies and on the macro variables (growth rate of GDP, interest rate). In $<$ table $6>$, the reported coefficient for the specific year indicates the bond-borrowing ratio's differences between the size cohort in that specific year and all the other firms in the whole sample period. $<$ Table $6>$ shows the regression results for the three size cohorts (top $1 \%$, top $6 \%$ - top $10 \%$, top $11 \%$ - top $20 \%$ ). The reason for choosing a different set of cohorts for $<$ table $4>$ is that, for the sample period, the small- and medium-sized firms (the cohorts we used in the regression analysis before) don't have any access to the borrowing from financial markets.

//Table 6 here//

After the crisis (in 1998-2000), the largest firms increase markedly the share of bond financing 
in total borrowing. The coefficients for 1998-2000 are around 0.4 (all significant), whereas the coefficients for 1992-1997 are smaller than 0.3 (also all significant).

For all the size cohorts, the share of bond financing in total asset increases gradually from 1992 to 1996 . This is due to the financial liberalization policy gradually taken by the government since the early 1990s. During this period the size of bond market in Korea gradually expanded. The bond market gets developed more rapidly with the speed-up of financial liberalization policy after the crisis.

\section{$<$ Empirical Distribution of Bond Financing for Different Cohorts >}

$<$ Figure 4-1-1 $>$ and $<$ Figure 4-1-2> show the bond-borrowing ratio distributions before and after the crisis for the largest cohort. After the crisis (in 1998-2000), the bond-borrowing ratio distribution for the largest firms shifts clearly to the right ( $<$ figure 4-1-2>).

//Figure 4-1-1 here//

//Figure 4-1-2 here//

In $<$ figure 4-2-1 $>$ and $<$ figure 4-2-2 $>$, we show the similar figures for another size cohort (top $11 \%$ - top $20 \%$ firms in asset size). This cohort is, in fact, the smallest firms to have any access to the bond market at all in the sample period. For this cohort, the loan-borrowing ratio distribution shifts to the right marginally before the crisis. After the crisis, however, the distribution shifts back to the left. There is a large peak around zero in 1999.and the distribution becomes degenerate in 2000 (i.e., this cohort does not have any access to bond market). A large proportion of the bonds that has been issued during the crisis, were under the risk of default, especially after the demise of the Daewoo group (one of the top four chaebols at that time in Korea) in 1999. This, in turn, put the whole market for corporate bonds into a state of malfunction in 1999 and in 
//Figure 4-2-1 here//

//Figure 4-2-2 here//

\section{Concluding Remarks}

The paper documents that large firms, to some extent, are leaving banks and going to the capital market for their financing after the crisis. ${ }^{6}$ The paper also shows that profitable small firms are gaining easier access to credit by financial institutions after the crisis. Financial institutions are reallocating their credit from large firms to small firms after the crisis. Why do we observe such shifts in the allocation of loans by financial institutions? Are they reflecting the firms' spontaneous choice for financing sources as a result of corporate restructuring? Otherwise, did the financial reform cause financial institutions to change their lending practices? The paper suggests that the banks' improved lending practices, at least partially, contributed to this shift.

\footnotetext{
${ }^{6}$ Clearly, the liberalization of financial markets, which happened at an accelerating rate after the crisis, contributed to broaden the supply base of various corporate financing sources. But, in Korea, deepening furthermore the supply base of various corporate financing sources still requires a better protection of investors' legitimate rights for various corporate financing tools.
} 


\section{References}

Hahm, Joon-Ho (2001), “The Government, Chaebol and Financial Institutions in Pre-Crisis Korea,” mimeo, Yonsei University.

Hahn, Chin-Hee (1999), "Implicit Loss-Protection and the Investment Behavior of Korean Chaebols: An Empirical Analysis," KDI Journal of Economic Policy, Vol. 21, No. 1, pp. 3-52. (in Korean)

Hoshi \& Kashap (1999), “The Japanese Banking Crisis”, NBER Macroeconomics Annual 1999

Joh, Sung-Wook (1999a), “The Korean Corporate Sector: Crisis and Reform,” mimeo, Korea Development Institute, August.

Joh, Sung-Wook (1999b), "Profitability of Korean Firms before the 1997 Economic Crisis," KDI Journal of Economic Policy, Vol. 21, No. 2, pp. 3-48. (in Korean)

Kim, Joon-Kyung (1999), "Policy Directions to Improve Ownership Structure of Financial Institutions," mimeo, Korea Development Institute. (in Korean)

Krueger, Anne O. and Jungho Yoo (2001), "Falling Profitability, Higher Borrowing Costs, and Chaebol Finances During the Korean Crisis" a paper presented at the Conference on the Korean Crisis and Recovery, Seoul, Korea

Yoo, Seong Min and Youngjae Lim (1999), "Big Business in Korea: New Learning and Policy Issues," Korea Development Institute Working Paper No. 9901, February. 

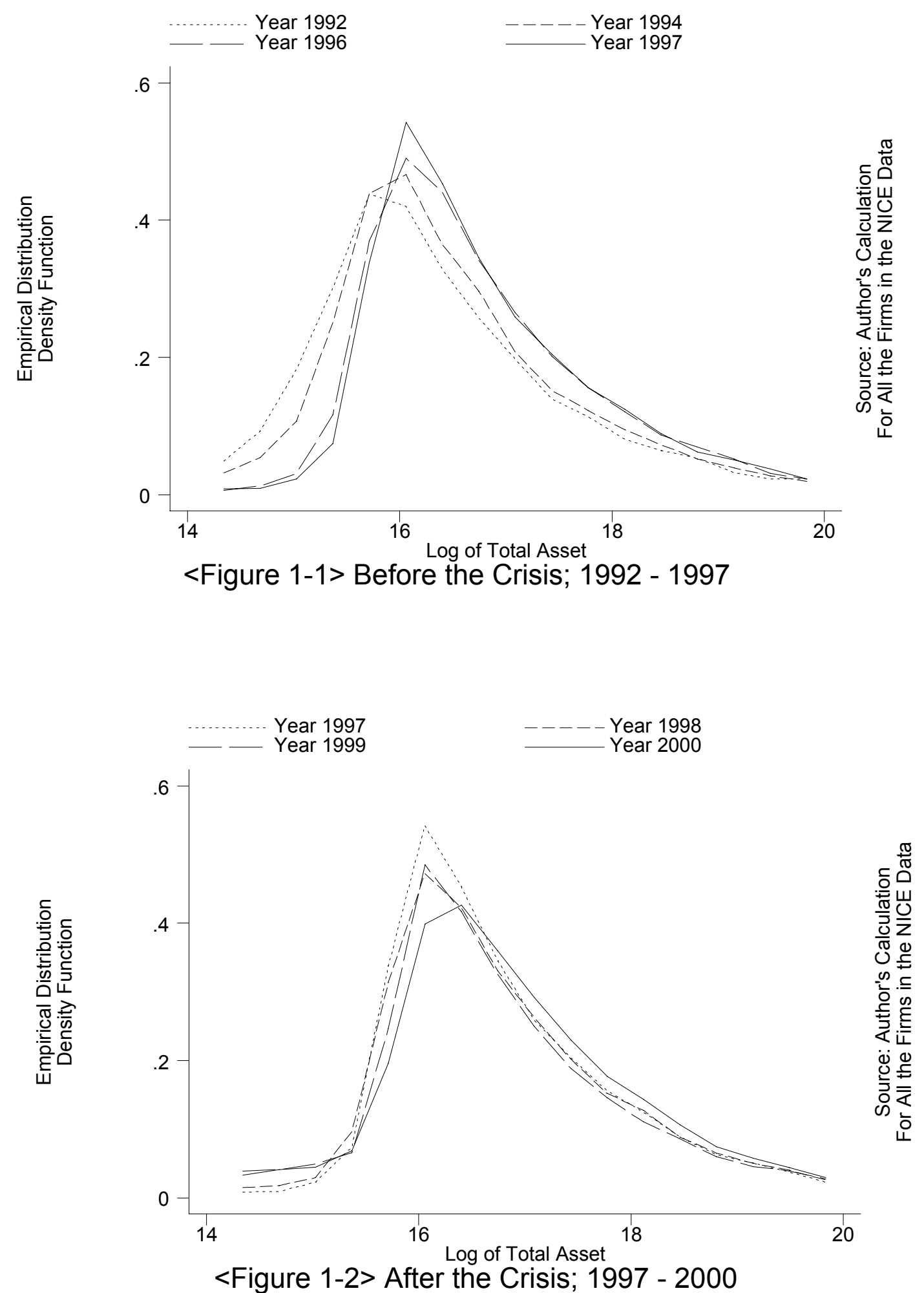


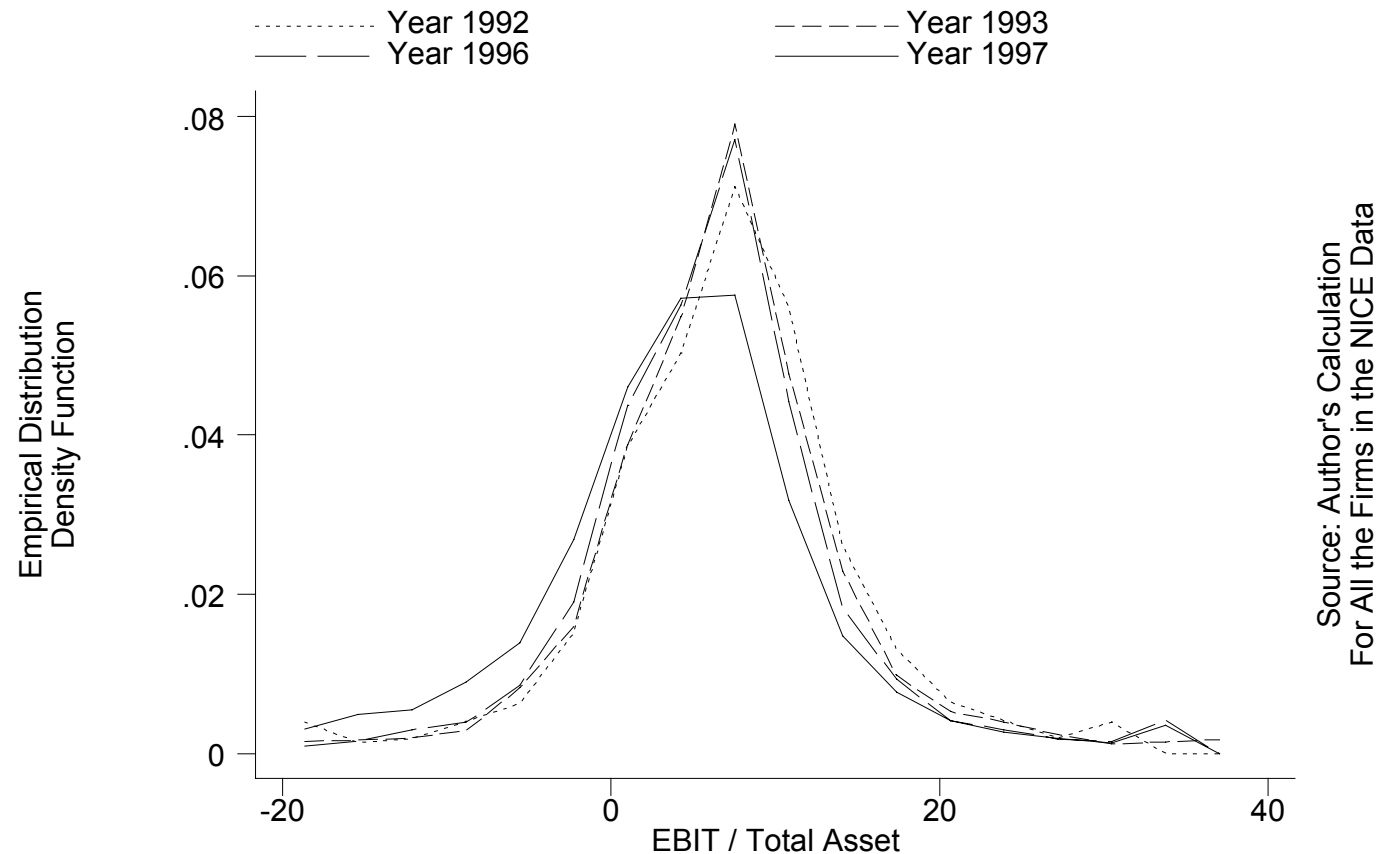

<Figure 2-1> Before the Crisis; 1992 - 1997

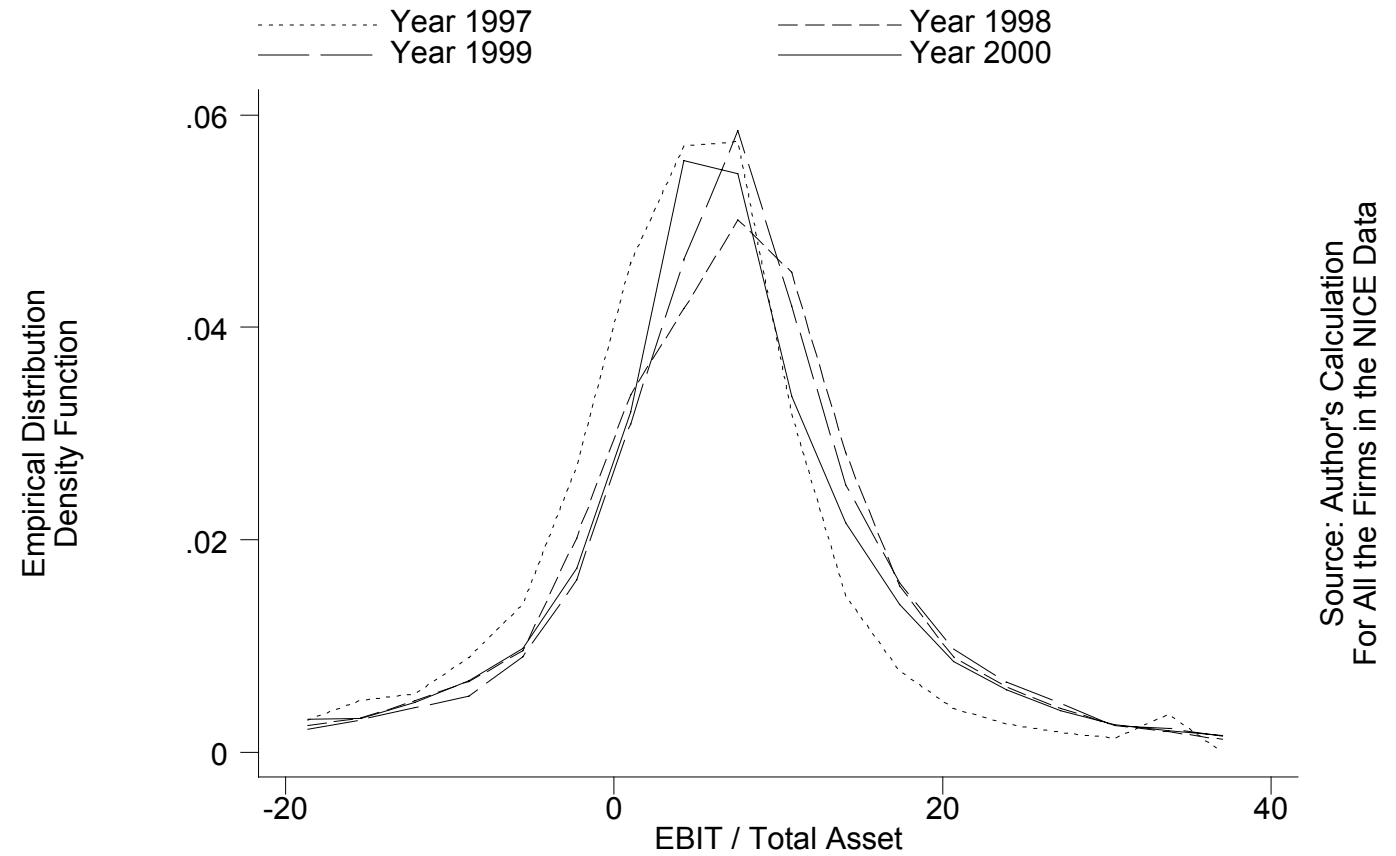

<Figure 2-2> After the Crisis; 1997 - 2000 


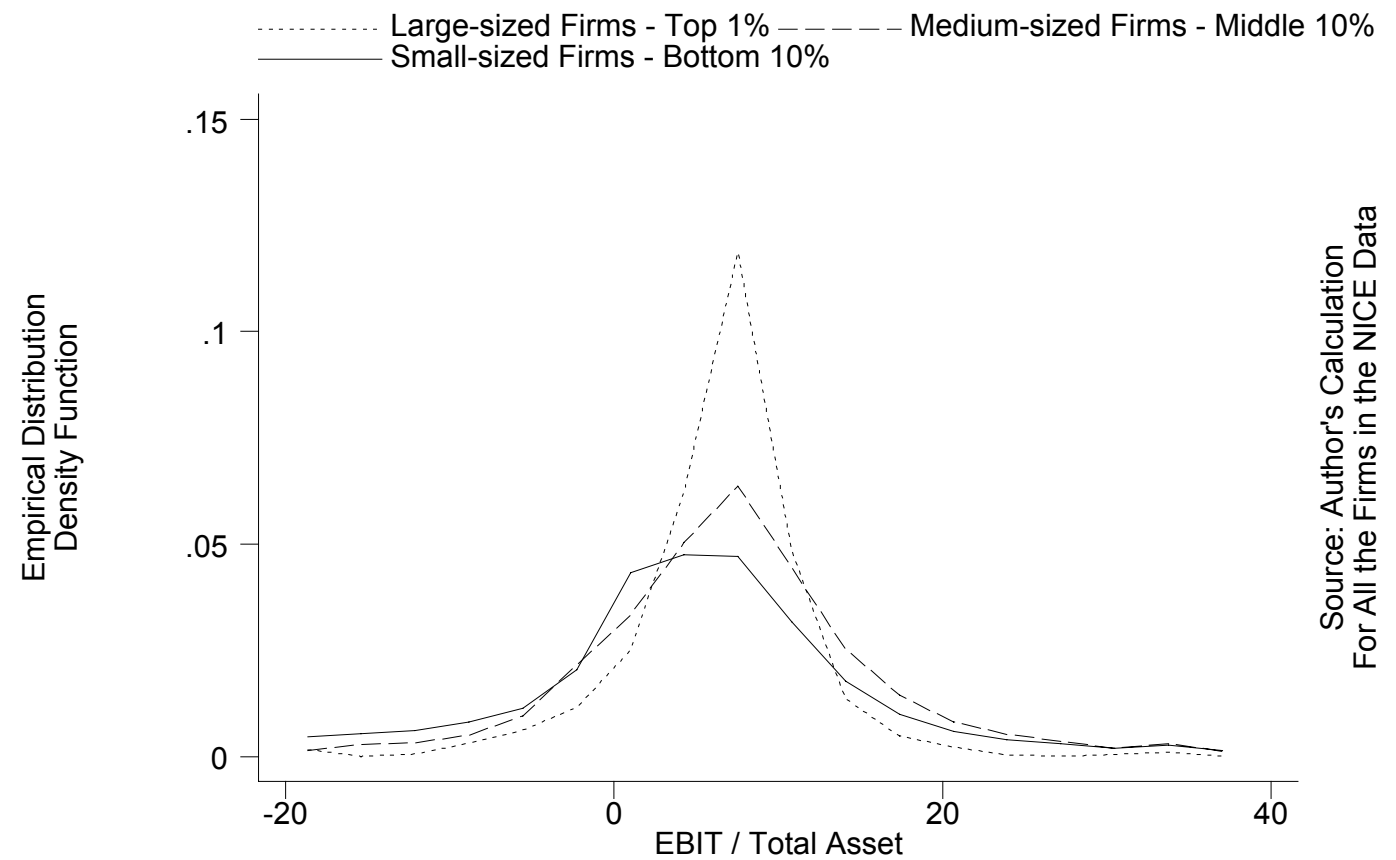

<Figure 2-3> Sample Period; 1992 - 2000 


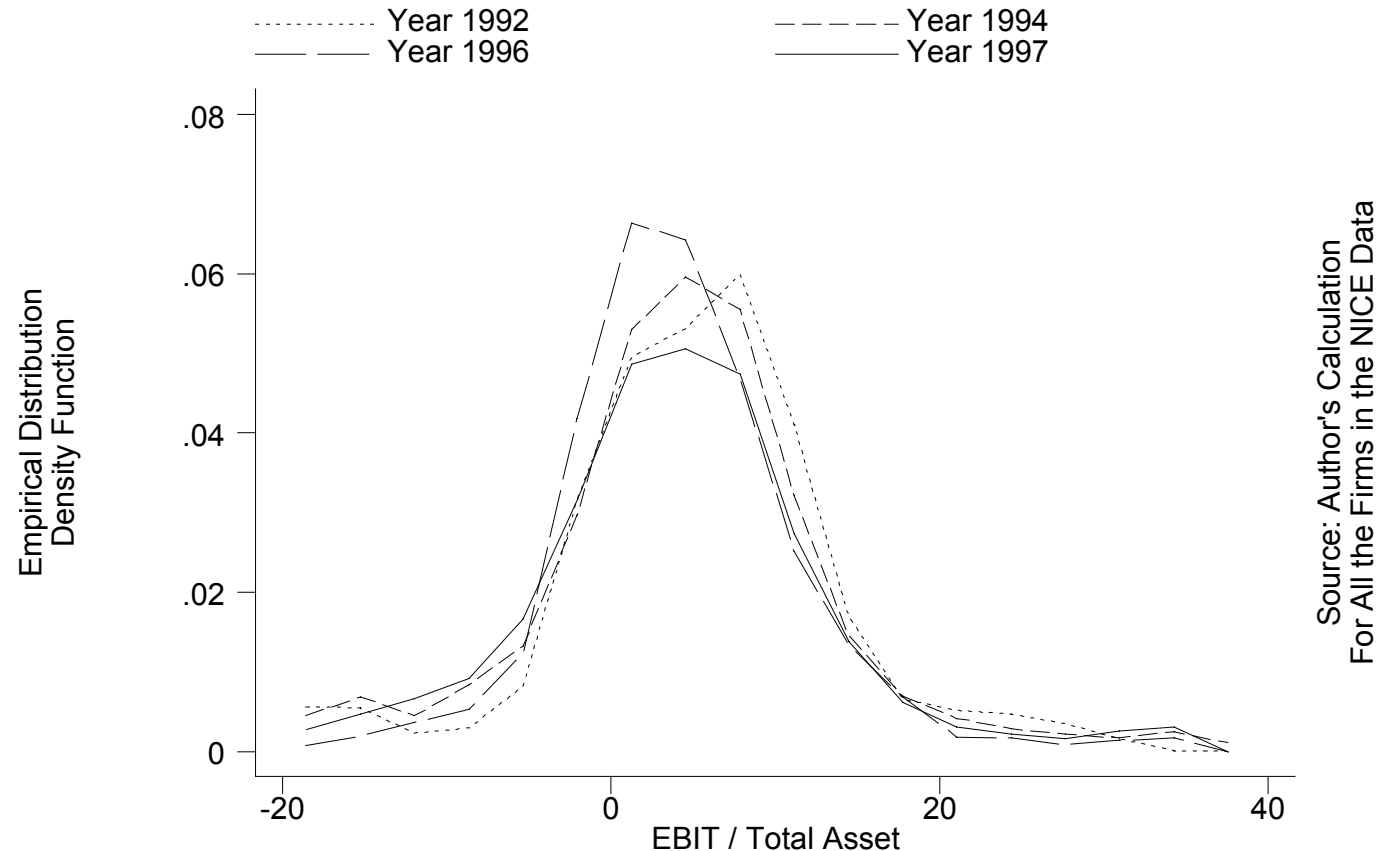

$<$ Figure 2-4-1> Small-sized Firms - Bottom 10\%; Before the Crisis

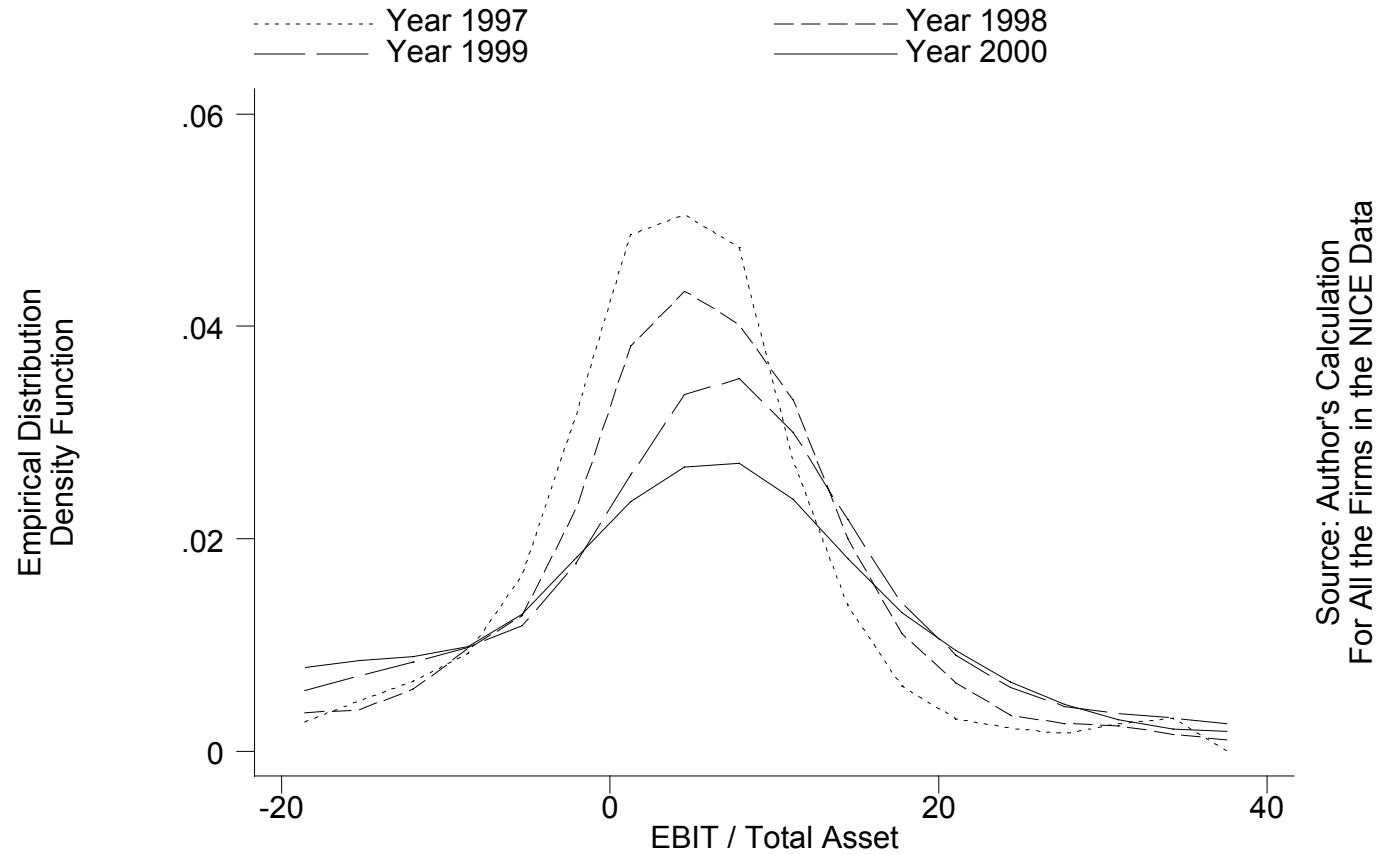

<Figure 2-4-2> Small-sized Firms - Bottom 10\%; After the Crisis 


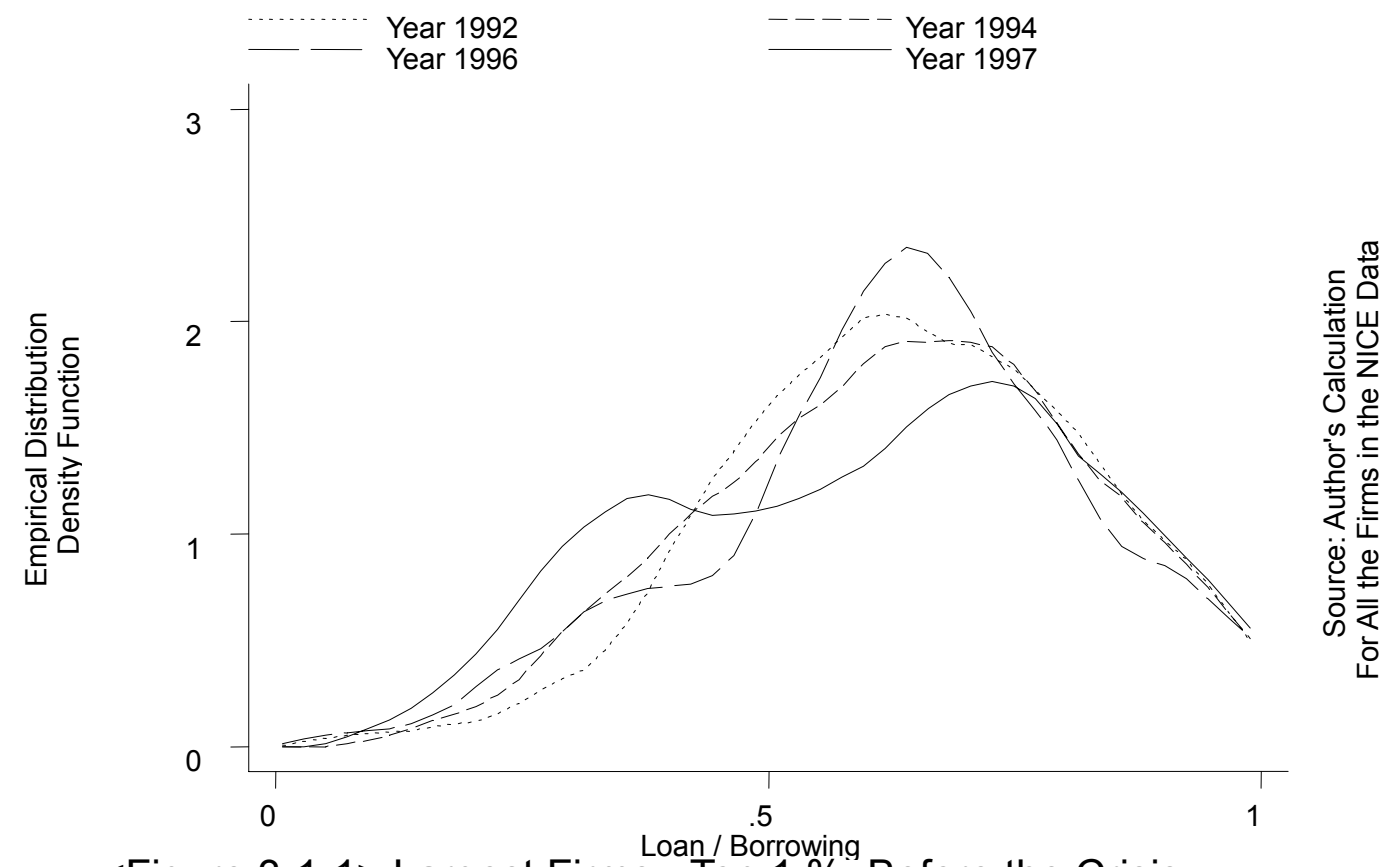

<Figure 3-1-1> Largest Firms - Top 1\%; Before the Crisis

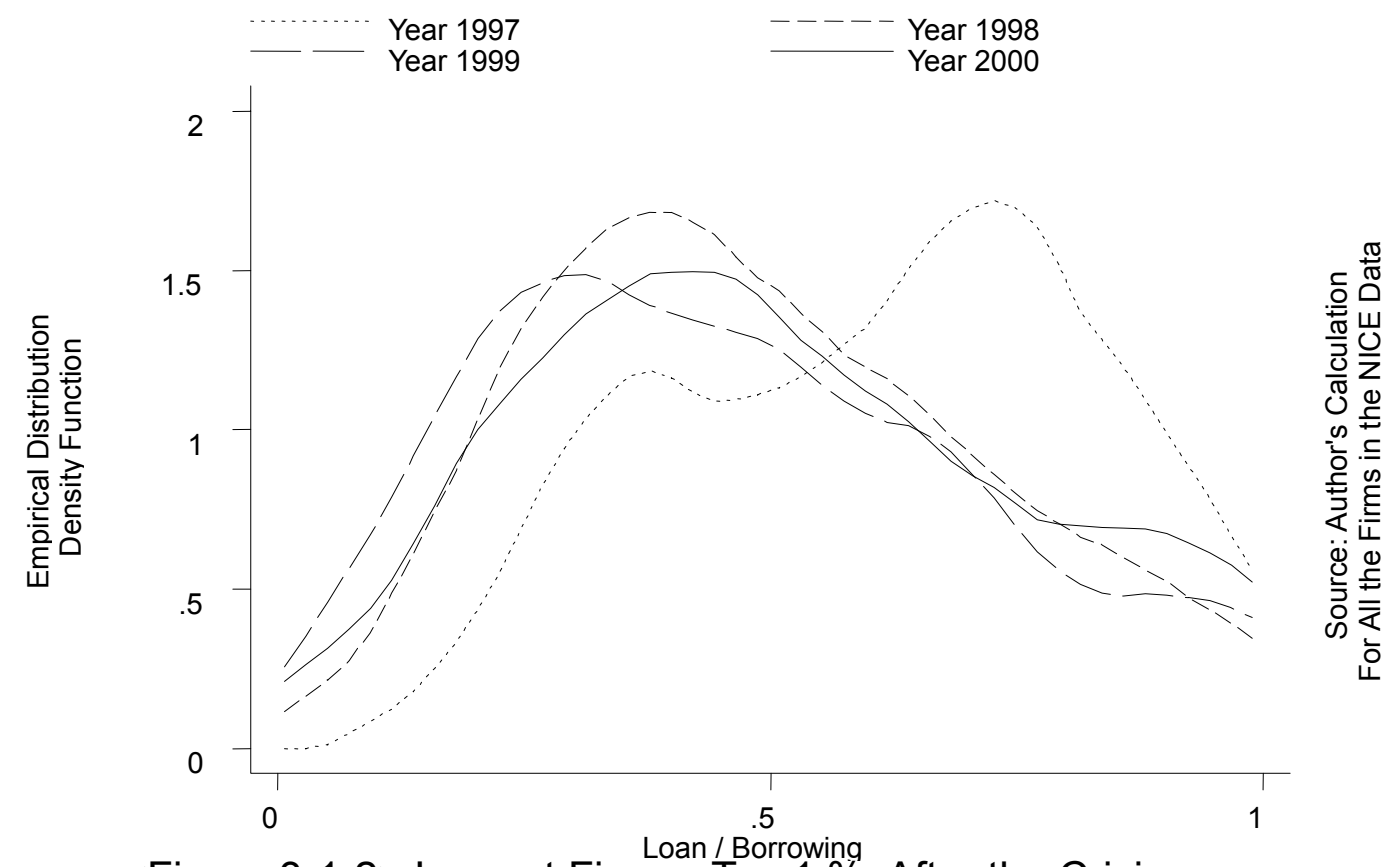

<Figure 3-1-2> Largest Firms - Top 1\%; After the Crisis 


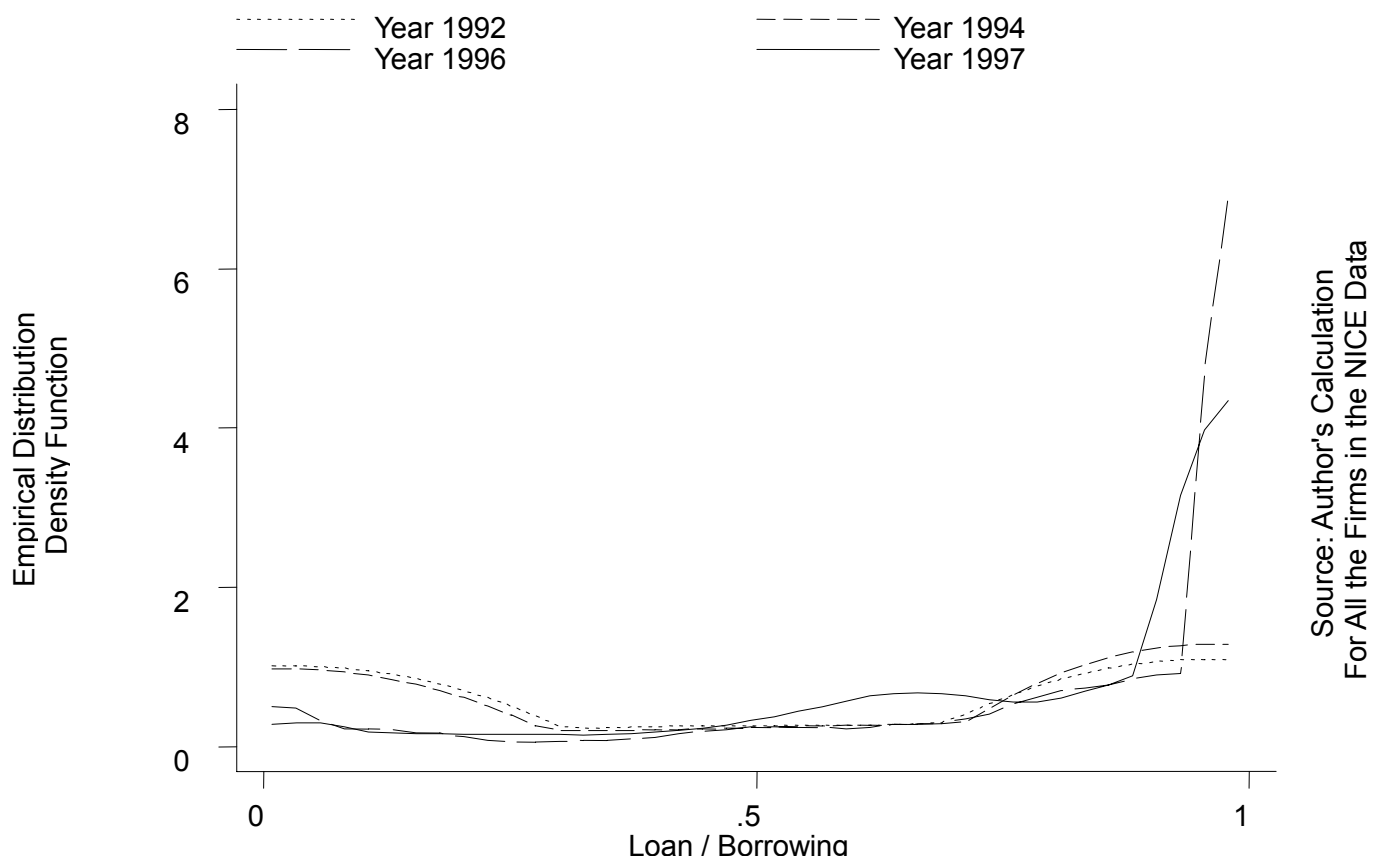

<Figure 3-2-1> Small-sized Firms - Bottom 10\%; Before the Crisis

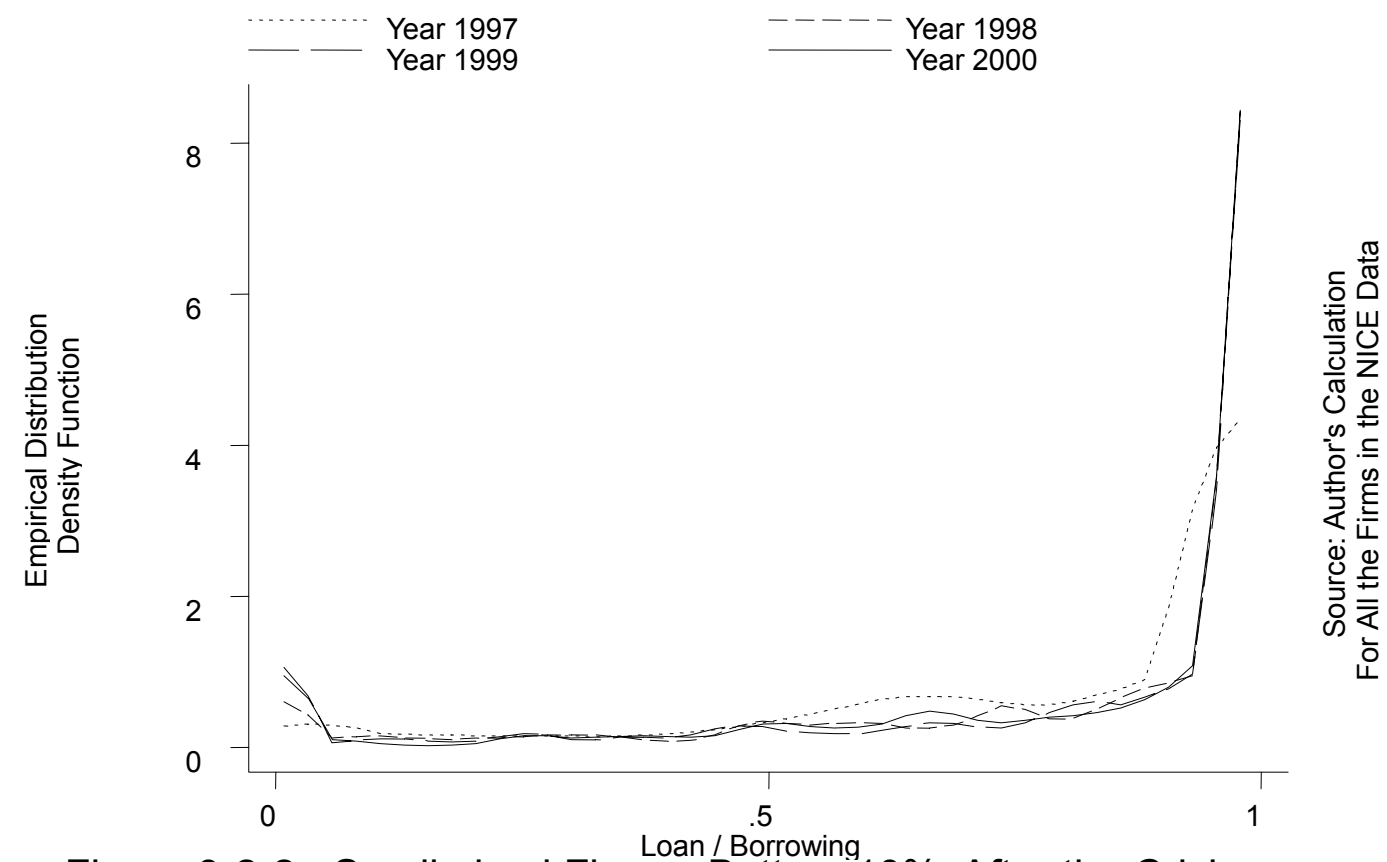

$<$ Figure 3-2-2> Small-sized Firms - Bottom 10\%; After the Crisis 


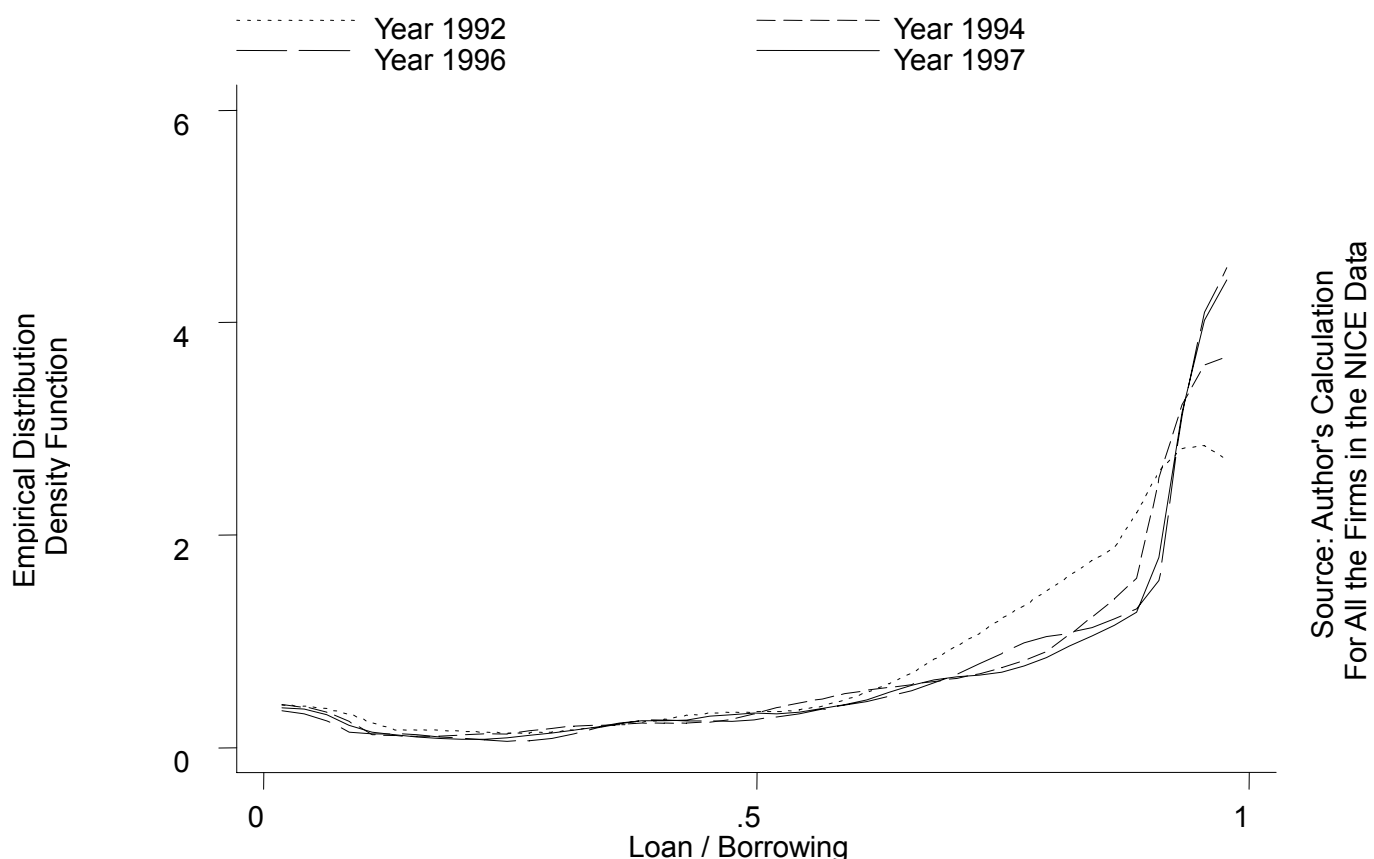

<Figure 3-3-1> Medium-sized Firms - Middle 10\%; Before the Crisis

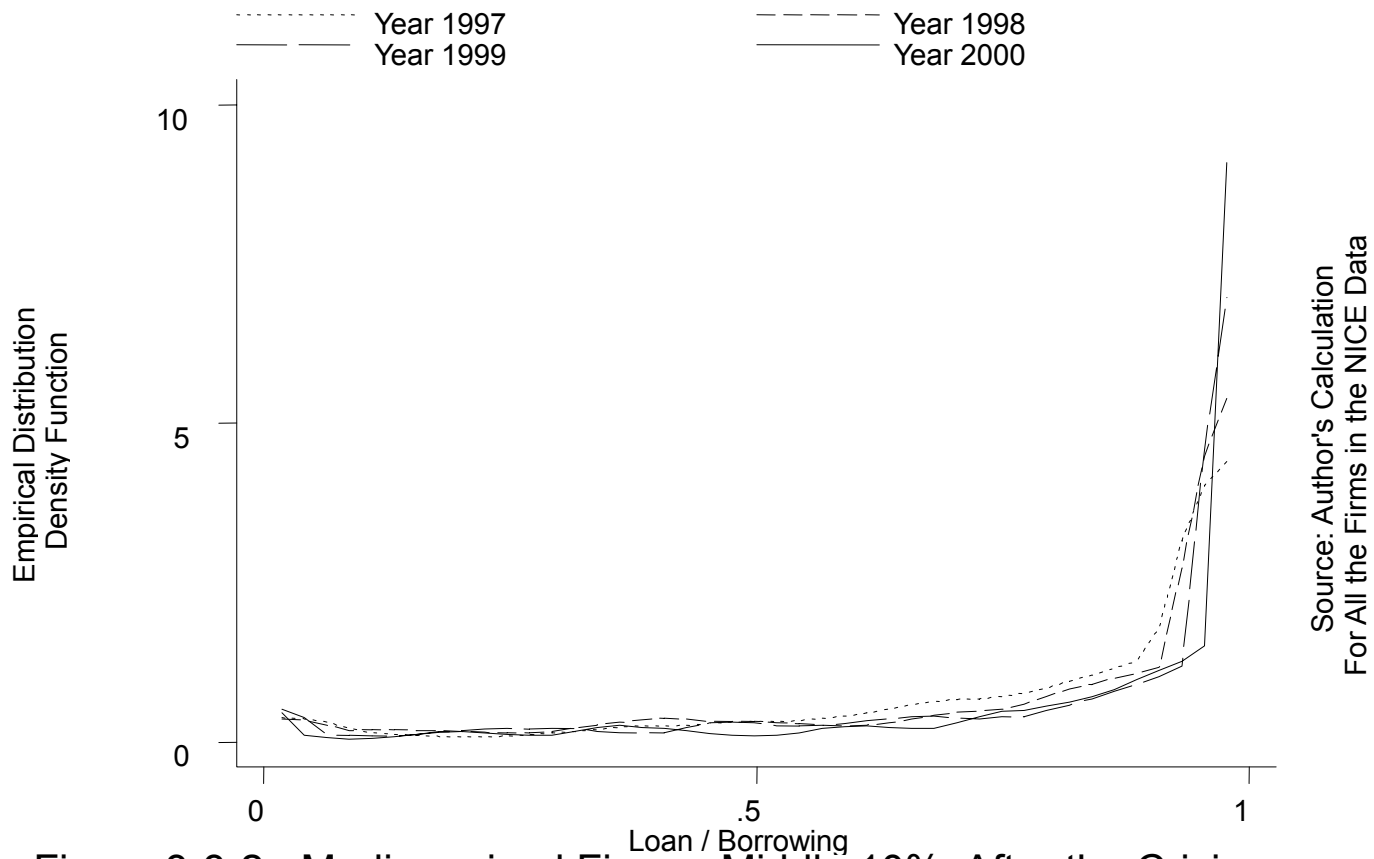

<Figure 3-3-2> Medium-sized Firms - Middle 10\%; After the Crisis 

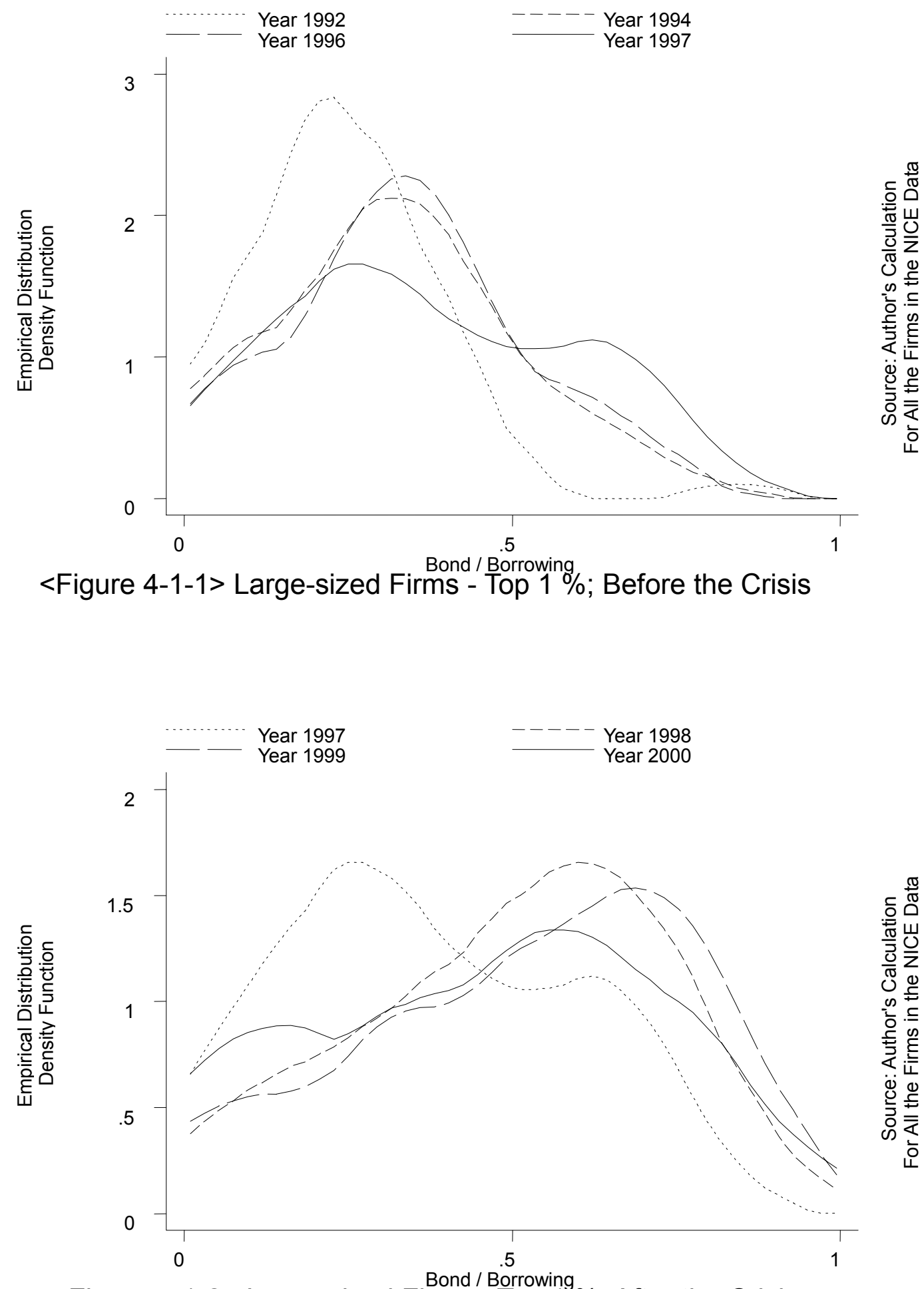

$<$ Figure 4-1-2> Large-sized Firms - Top 1\%; After the Crisis 


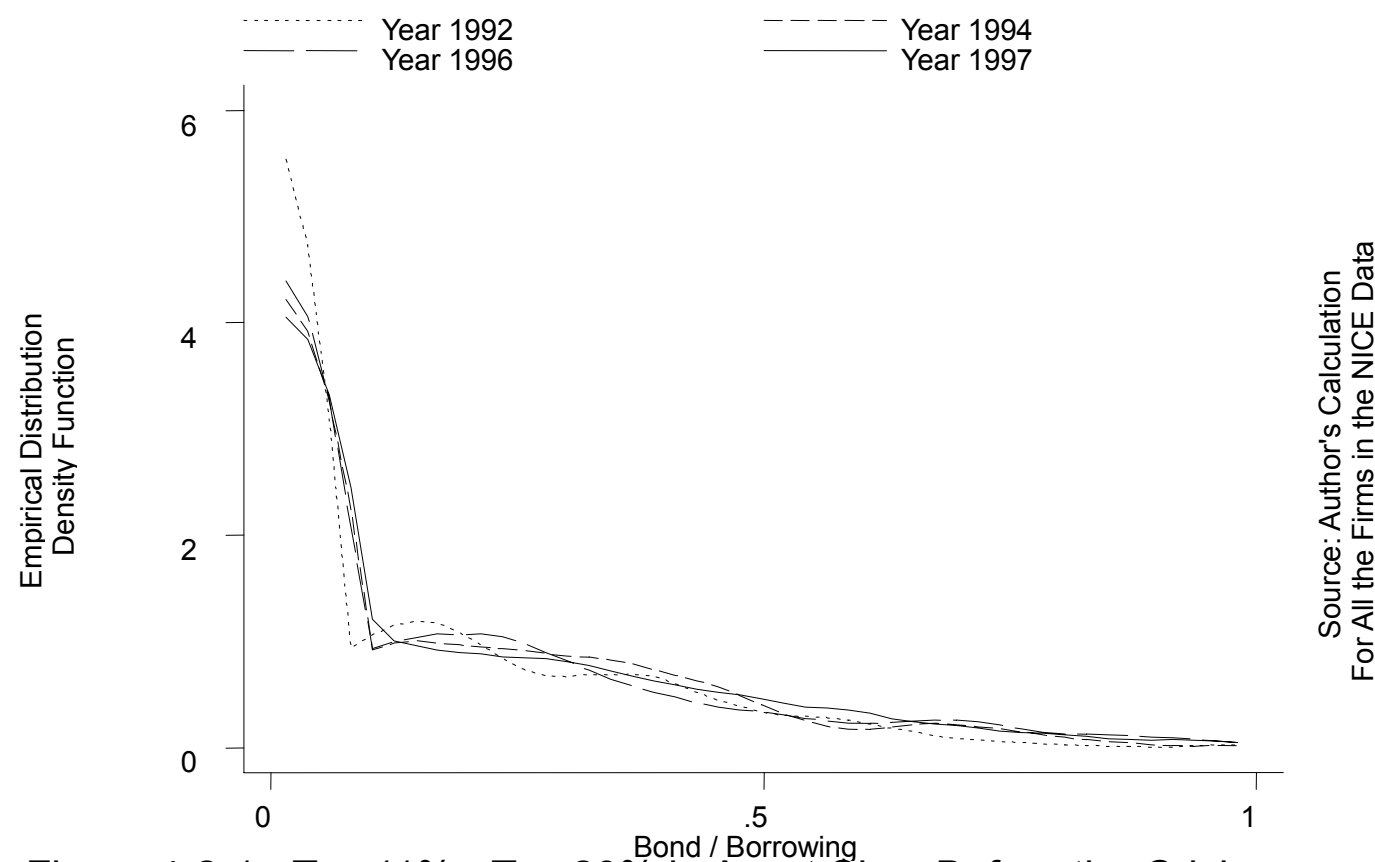

$<$ Figure 4-2-1> Top 11\% - Top 20\% in Asset Size; Before the Crisis

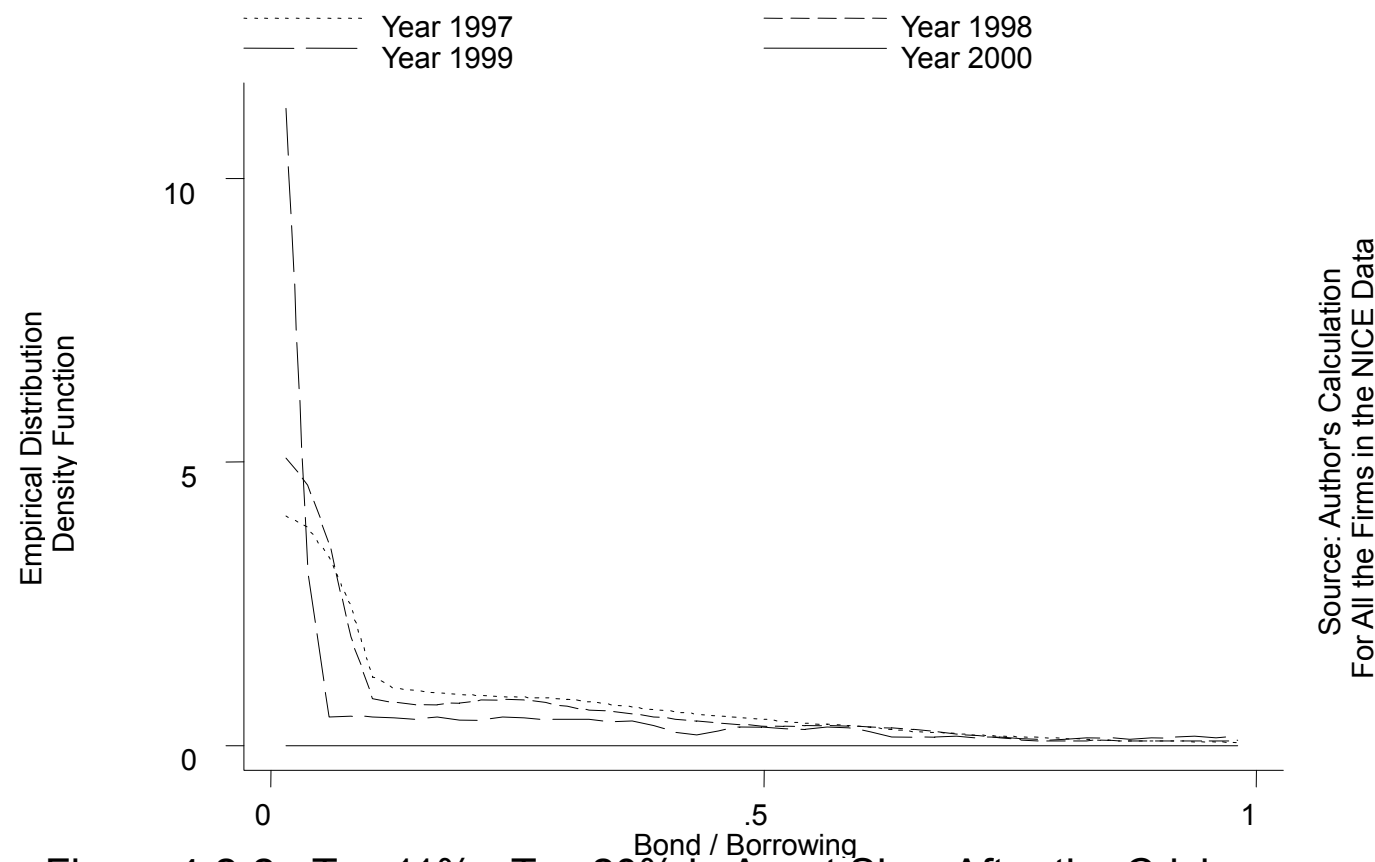

$<$ Figure 4-2-2> Top 11\% - Top 20\% in Asset Size; After the Crisis 
Table 1. Sources of Corporate Financing (Flows)

For All the Firms in the Korean Economy

$1992-2000$

\begin{tabular}{|c|c|c|c|c|c|c|c|c|c|}
\hline & 1992 & 1993 & 1994 & 1995 & 1996 & 1997 & 1998 & 1999 & 2000 \\
\hline Total Finance & 100.0 & 100.0 & 100.0 & 100.0 & 100.0 & 100.0 & 100.0 & 100.0 & - \\
\hline Retained Earnings & 28.7 & 30.0 & 27.3 & 27.9 & 22.6 & 27.1 & 50.0 & 49.4 & - \\
\hline External Finance & 71.3 & 70.0 & 72.7 & 72.1 & 77.4 & 72.9 & 50.0 & 50.6 & - \\
\hline External Finance & 100.0 & 100.0 & 100.0 & 100.0 & 100.0 & 100.0 & 100.0 & 100.0 & 100.0 \\
\hline Indirect Finance & 36.3 & 31.4 & 44.5 & 31.8 & 28.0 & 36.8 & -57.3 & 4.1 & 17.1 \\
\hline Commercial Banks & 15.1 & 13.1 & 20.7 & 14.9 & 14.0 & 12.9 & 2.5 & 29.2 & 35.2 \\
\hline Insurance Companies & 3.9 & 3.1 & 2.4 & 2.7 & 2.8 & 2.3 & -20.8 & 0.5 & 3.1 \\
\hline $\begin{array}{l}\text { Short-term Finance } \\
\text { Companies } \\
\text { (e.g., Merchant Banks) }\end{array}$ & -0.4 & 2.4 & 4.3 & 0.5 & -0.4 & 1.8 & -22.4 & -2.6 & -6.8 \\
\hline $\begin{array}{l}\text { Other Non-bank } \\
\text { Financial ntermediaries }\end{array}$ & 17.7 & 12.8 & 17.1 & 13.7 & 11.5 & 19.8 & -16.7 & -22.9 & -14.4 \\
\hline Direct Finance & 38.9 & 49.1 & 36.5 & 48.1 & 47.2 & 37.4 & 178.9 & 46.8 & 28.6 \\
\hline Government Bonds & 3.3 & 3.4 & 0.4 & -0.9 & 0.3 & 0.5 & 2.0 & 0.0 & -2.2 \\
\hline Commercial Paper & 7.6 & 13.9 & 4.9 & 16.1 & 17.5 & 3.7 & -42.2 & -30.4 & -1.7 \\
\hline Corporate Bonds & 12.1 & 14.5 & 14.2 & 15.3 & 17.9 & 23.3 & 165.9 & -5.3 & -3.2 \\
\hline Equity & 15.9 & 17.3 & 17.0 & 17.6 & 11.6 & 9.9 & 53.2 & 82.6 & 35.6 \\
\hline Foreign Borrowing & 7.1 & 1.5 & 6.6 & 8.4 & 10.4 & 5.6 & -35.5 & 24.1 & 23.7 \\
\hline $\begin{array}{l}\text { Borrowing from } \\
\text { Government }\end{array}$ & 1.0 & -0.2 & 0.2 & 0.2 & -0.2 & 1.4 & 5.8 & 3.6 & 7.4 \\
\hline Inter-firm Credit & 8.9 & 9.0 & 6.9 & 5.0 & 6.8 & 10.6 & -27.2 & 10.2 & 6.8 \\
\hline Etc & 7.9 & 9.2 & 5.3 & 6.5 & 7.8 & 8.4 & 35.3 & 11.1 & 16.5 \\
\hline
\end{tabular}

Source: Author's own calculation from the information in each issue of the Flow of Funds. 
Table 2 -1. Summary Statistics of Firm-level Data

\begin{tabular}{|l|c|c|c|}
\hline \multirow{2}{*}{} & \multicolumn{2}{|c|}{ All the Firms in the Sample(Number of the Firms: 11026) } \\
\cline { 2 - 5 } & $1992-1996$ & $1997-1998$ & $1999-2000$ \\
\hline \hline \multirow{2}{*}{$\begin{array}{l}\text { EBIT/Asset } \\
\text { Borrowing/Asset }\end{array}$} & 6.615775 & 3.799436 & 4.627726 \\
\hline $\begin{array}{l}\text { Loans from Financial } \\
\text { Institutions/Borrowing }\end{array}$ & 0.386551 & 0.437128 & 0.379096 \\
\hline $\begin{array}{l}\text { Bond } \\
\text { Financing/Borrowing }\end{array}$ & 0.76436 & & 0.83345 \\
\hline
\end{tabular}


Table 2-2. Summary Statistics for the Three size Cohorts in Firm -level Data

\begin{tabular}{|c|c|c|c|c|c|c|c|c|c|}
\hline & \multicolumn{3}{|c|}{$\begin{array}{l}\text { Large Firms } \\
\text { (Top } 1 \% \text { in asset size, } \mathrm{n}=81 \text { ) }\end{array}$} & \multicolumn{3}{|c|}{$\begin{array}{l}\text { Medium-sized Firms } \\
\text { (Middle } 10 \% \text { in asset size, } \mathrm{n}=1039 \text { ) }\end{array}$} & \multicolumn{3}{|c|}{$\begin{array}{c}\text { Small Firms } \\
\text { (Bottom 10\% in asset size, } \mathrm{n}=1967 \text { ) }\end{array}$} \\
\hline & 1992-1996 & 1997-1998 & $1999-2000$ & $1992-1996$ & 1997-1998 & $1999-2000$ & 1992-1996 & 1997-1998 & $1999-2000$ \\
\hline Asset & 3111.022 & 5552.276 & 6424.852 & 12.11443 & 16.53895 & 18.95957 & 3.986525 & 5.635815 & 4.590203 \\
\hline EBIT/Asset & 7.155734 & 3.316438 & 1.834255 & 6.844423 & 5.624044 & 7.342637 & 4.505347 & -0.02398 & -4.61268 \\
\hline Borrowing/Asset & 0.493031 & 0.575053 & 0.471116 & 0.409815 & 0.430318 & 0.376597 & 0.274567 & 0.437087 & 0.340989 \\
\hline $\begin{array}{l}\text { Loans from Financial } \\
\text { Institutions/Borrowing }\end{array}$ & 0.644068 & 0.559247 & 0.495934 & 0.805886 & 0.831305 & 0.864931 & 0.646217 & 0.848398 & 0.846132 \\
\hline $\begin{array}{l}\text { Bond } \\
\text { Financing/Borrowing }\end{array}$ & 0.292236 & 0.430513 & 0.480812 & 0.0372 & 0.041568 & 0.021368 & 0.013683 & 0.021823 & 0.017426 \\
\hline
\end{tabular}


Table 3. Test of Loan-Dependency for Size Cohorts

\begin{tabular}{|c|c|c|c|}
\hline \multirow{2}{*}{$\begin{array}{c}\text { Independent } \\
\text { Variables : } \\
\text { Dummy Variable } \\
\text { Denoting a } \\
\text { Specific Cohort } \\
\text { Interacted with } \\
\text { Year Dummies } \\
\end{array}$} & \multicolumn{3}{|c|}{$\begin{array}{c}\text { Dependent variable } \\
\text { Borrowing from Financial Intermediaries / Total Borrowing }\end{array}$} \\
\hline & $\begin{array}{c}\text { Large-sized Firms } \\
\text { Top } 1 \% \text { in Asset } \\
\text { Size }\end{array}$ & $\begin{array}{l}\text { Medium-sized } \\
\text { Firms } \\
\text { Middle } 10 \% \text { in } \\
\text { Asset Size }\end{array}$ & $\begin{array}{c}\text { Small-sized Firms } \\
\text { Bottom } 10 \% \text { in Asset } \\
\text { Size }\end{array}$ \\
\hline 1992 & $\begin{array}{l}-0.0921139^{* *} \\
\quad(-2.62)\end{array}$ & $\begin{array}{l}0.0387634 * * \\
\quad(2.87)\end{array}$ & $\begin{array}{l}-0.2384735^{* *} \\
\quad(-13.00)\end{array}$ \\
\hline 1993 & $\begin{array}{c}-0.1586578 * * \\
(-4.55)\end{array}$ & $\begin{array}{c}-0.0235114 * \\
(-1.84)\end{array}$ & $\begin{array}{l}-0.2903267 * * \\
(-18.11)\end{array}$ \\
\hline 1994 & $\begin{array}{l}-0.1421788^{* *} \\
\quad(-4.14)\end{array}$ & $\begin{array}{l}0.0256183^{* *} \\
\quad(2.16)\end{array}$ & $\begin{array}{l}-0.2288625^{* *} \\
(-14.64)\end{array}$ \\
\hline 1995 & $\begin{array}{c}-0.1293241 * * \\
(-3.79)\end{array}$ & $\begin{array}{l}0.0597968 * * \\
\quad(5.29)\end{array}$ & $\begin{array}{l}-0.0301975 * * \\
(-1.99)\end{array}$ \\
\hline 1996 & $\begin{array}{l}-0.167552 * * \\
(-4.91)\end{array}$ & $\begin{array}{l}0.0308845^{* *} \\
\quad(2.77)\end{array}$ & $\begin{array}{l}0.0537893^{* *} \\
\quad(3.42)\end{array}$ \\
\hline 1997 & $\begin{array}{c}-0.1678041^{* *} \\
(-4.96)\end{array}$ & $\begin{array}{l}0.0447281^{* *} \\
(4.27)\end{array}$ & $\begin{array}{l}0.0459803^{* * *} \\
\quad(4.15)\end{array}$ \\
\hline 1998 & $\begin{array}{l}-0.3016408 * * \\
(-8.87)\end{array}$ & $\begin{array}{l}0.0420476^{* *} \\
\quad(3.67)\end{array}$ & $\begin{array}{l}0.0702478^{* *} \\
\quad(5.88)\end{array}$ \\
\hline 1999 & $\begin{array}{l}-0.3210245^{* *} \\
\quad(-9.54)\end{array}$ & $\begin{array}{l}0.0575082 * * \\
\quad(5.51)\end{array}$ & $\begin{array}{l}0.044566^{* *} \\
\quad(4.97)\end{array}$ \\
\hline 2000 & $\begin{array}{c}-0.3293786 * * \\
(-9.84)\end{array}$ & $\begin{array}{l}0.0455123 * * \\
\quad(4.06)\end{array}$ & $\begin{array}{c}0.012498 \\
(1.21)\end{array}$ \\
\hline $\begin{array}{l}\text { GDP Growth } \\
\text { Rate }\end{array}$ & $\begin{array}{c}-0.003067 * * \\
(-10.53)\end{array}$ & $\begin{array}{c}-0.0030401 * * \\
(-9.93)\end{array}$ & $\begin{array}{l}-0.0022235^{* * *} \\
(-7.36)\end{array}$ \\
\hline $\begin{array}{c}\text { Yields to } \\
\text { Corporate Bonds }\end{array}$ & $\begin{array}{c}-0.0161758^{* * *} \\
(-20.77)\end{array}$ & $\begin{array}{c}-0.015893 * * \\
(-19.42)\end{array}$ & $\begin{array}{c}-0.0137879 * * \\
(-17.11)\end{array}$ \\
\hline $\begin{array}{l}\text { Number of } \\
\text { observations }\end{array}$ & 56,990 & 56,990 & 56,990 \\
\hline
\end{tabular}

Note: 1 . Number in the parenthesis are t-values.

2. * significant at the $10 \%$ significance level.

** significant at the $5 \%$ significance level.

3. Bond-dependency ratio refers to the borrowing from financial markets divided by total borrowing. 
Table 4. Determinant of Loans for the Small-sized Firms

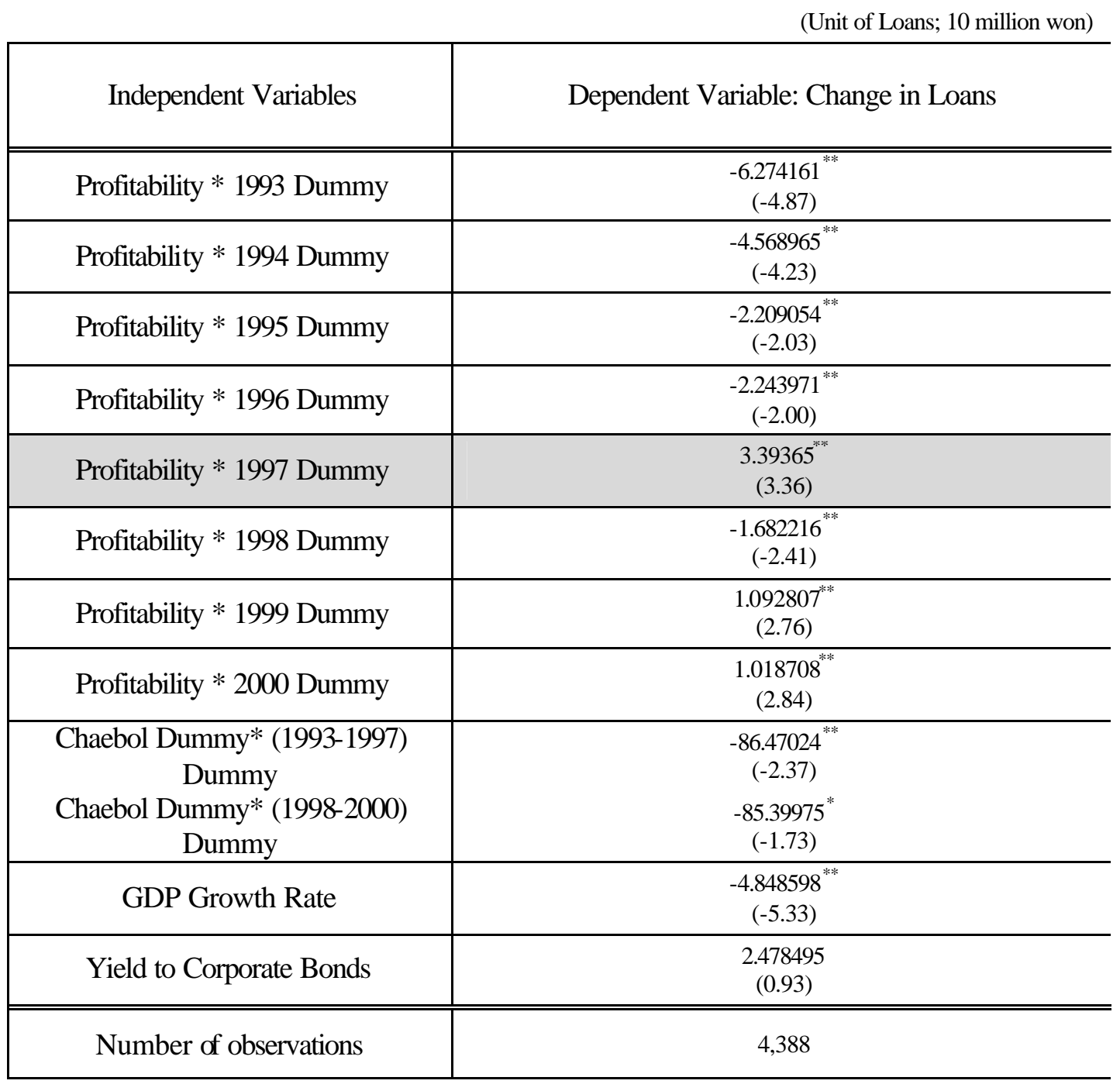

Note: 1. Number in the parenthesis are t-values.

2. * significant at the $10 \%$ significance level.

** significant at the 5\% significance level.

3. Profitability refers to the EBIT divided by total assets. 
Table 5. Test of Borrowing-Dependency for Size Cohorts

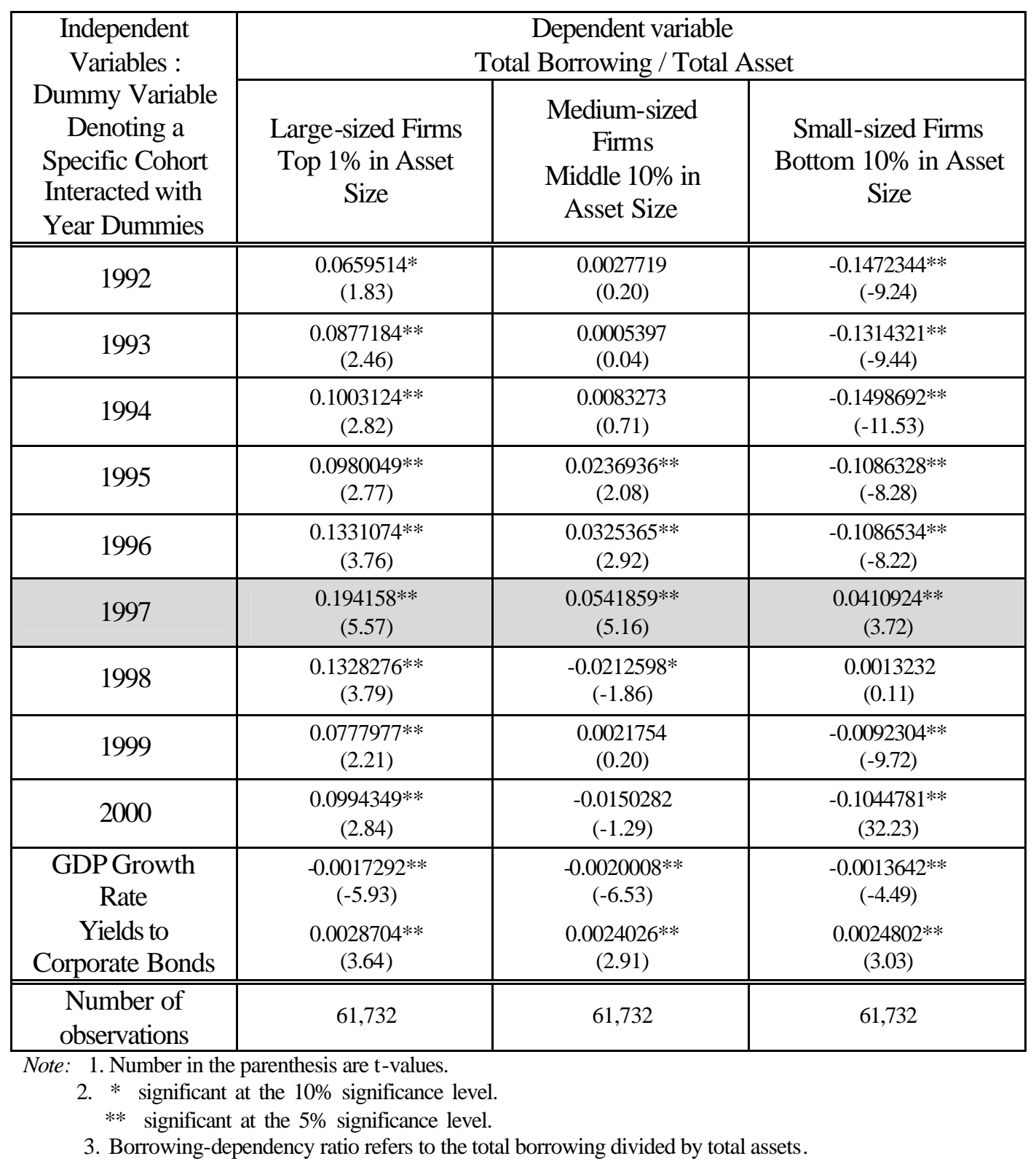


Table 6. Test of Bond-Dependency for Size Cohorts

\begin{tabular}{|c|c|c|c|}
\hline \multirow{2}{*}{$\begin{array}{c}\text { Independent } \\
\text { Variables : } \\
\text { Dummy Variable } \\
\text { Denoting a } \\
\text { Specific Cohort } \\
\text { Interacted with } \\
\text { Year Dummies } \\
\end{array}$} & \multicolumn{3}{|c|}{$\begin{array}{l}\text { Dependent variable } \\
\text { Borrowing from Financial Markets / Total Borrowing }\end{array}$} \\
\hline & $\begin{array}{c}\text { Large-sized Firms } \\
\text { Top } 1 \% \text { in Asset } \\
\text { Size }\end{array}$ & $\begin{array}{l}\text { Top 6\% - Top } 10 \% \\
\text { in Asset Size }\end{array}$ & $\begin{array}{l}\text { Top } 11 \% \text { - Top } 20 \% \\
\text { In Asset Size }\end{array}$ \\
\hline 1992 & $\begin{array}{l}0.1606923^{* *} \\
\quad(2.62)\end{array}$ & $\begin{array}{l}0.1033503 * * \\
\quad(11.35)\end{array}$ & $\begin{array}{l}0.0474412^{* * *} \\
\quad(6.94)\end{array}$ \\
\hline 1993 & $\begin{array}{l}0.1858304 * * \\
\quad(4.55)\end{array}$ & $\begin{array}{l}0.1329246^{* * *} \\
\quad(14.98)\end{array}$ & $\begin{array}{l}0.0737644^{* *} \\
\quad(11.17)\end{array}$ \\
\hline 1994 & $\begin{array}{l}0.2457253^{* *} \\
\quad(4.14)\end{array}$ & $\begin{array}{l}0.1504895^{* *} \\
\quad(17.09)\end{array}$ & $\begin{array}{l}0.0773101^{* *} \\
\quad(11.96)\end{array}$ \\
\hline 1995 & $\begin{array}{c}0.2486298^{* *} \\
(3.79)\end{array}$ & $\begin{array}{c}0.1569188^{* * *} \\
(17.78)\end{array}$ & $\begin{array}{c}0.0757029 * * \\
(11.76)\end{array}$ \\
\hline 1996 & $\begin{array}{l}0.2660462 * * \\
\quad(4.91)\end{array}$ & $\begin{array}{l}0.1723627 * * \\
\quad(19.57)\end{array}$ & $\begin{array}{l}0.0849736^{* * *} \\
\quad(13.27)\end{array}$ \\
\hline 1997 & $\begin{array}{l}0.2972274 * * \\
\quad(4.96)\end{array}$ & $\begin{array}{c}0.1714493 * * \\
(19.65)\end{array}$ & $\begin{array}{c}0.0874618^{* * *} \\
(13.98)\end{array}$ \\
\hline 1998 & $\begin{array}{c}0.4214115^{* * *} \\
(8.87)\end{array}$ & $\begin{array}{c}0.1781424 * * \\
\quad(19.35)\end{array}$ & $\begin{array}{c}0.0676496^{* * *} \\
(9.98)\end{array}$ \\
\hline 1999 & $\begin{array}{c}0.4463751^{* * *} \\
(9.54)\end{array}$ & $\begin{array}{c}0.1964039 * * \\
(21.32)\end{array}$ & $\begin{array}{c}0.0492785^{* * *} \\
(7.50)\end{array}$ \\
\hline 2000 & $\begin{array}{c}0.393401 * * \\
(9.84)\end{array}$ & $\begin{array}{c}0.1600738 * * \\
(17.17)\end{array}$ & $\begin{array}{c}0.0332003^{* * *} \\
(4.79)\end{array}$ \\
\hline $\begin{array}{c}\text { GDP Growth } \\
\text { Rate } \\
\text { Yields to } \\
\text { Corporate Bonds }\end{array}$ & $\begin{array}{c}0.0001438 * * \\
(-10.53) \\
0.0031343 * * \\
(-20.77)\end{array}$ & $\begin{array}{c}0.0000674 \\
(0.39) \\
0.0028533 * * \\
(6.21) \\
\end{array}$ & $\begin{array}{c}-9.01 \mathrm{e}-06 \\
(-0.05) \\
0.0022457 * * \\
(4.67) \\
\end{array}$ \\
\hline $\begin{array}{l}\text { Number of } \\
\text { observations }\end{array}$ & 56,990 & 56,990 & 56,990 \\
\hline
\end{tabular}

Note: 1. Number in the parenthesis are t-values.

2. * significant at the $10 \%$ significance level.

** significant at the 5\% significance level.

3. Bond-dependency ratio refers to the borrowing from financial markets divided by total borrowing. 